\section{Red fox (Vulpes vulpes) as a synurbic species and its role in the spread of the Echinococcus multilocularis tapeworm}

Dorota Dwużnik, Anna Bajer

\section{DOI: $10.24131 / 3247.180104$}

Summary:

Urbanization of the environment contributes to the degradation of many natural habitats of many plants and animals, which causes reduction of biodiversity. There are however certain species, adapting easily to both suburban and urban conditions. Red fox (Vulpes vulpes) is a good example, since it is increasingly noted not only in the natural habitats, such as fields or forests, but also in the direct vicinity of human residencies like farms, suburban areas or even large agglomerations. Fox is becoming a permanent feature of urban fauna, enriching the biodiversity. It is also a relevant epidemiological threat, constituting a zoonotic reservoir for many parasites which are important from veterinary, as well as from medical point of view, including tapeworm Echinococcus multilocularis which causes alveolar echinococcosis.

Key words: red fox, rabies, scabies, alveolar echinococcosis, hunting, parasites, Echinococcus multilocularis

received: 8.09.2017; accepted: 10.10.2017; published: 13.12.2017

mgr Dorota Dwużnik: Faculty of Biology University of Warsaw

\section{Introduction}

The progressing urbanization process causes the displacement of numerous plant and animal species from their current habitats, thus contributing to the reduction of biodiversity (Vitousek et al., 1997; Hunter, 2007). However, some animals are capable of overcoming the fear of humans and learn how to use new ecological niches resulting from human activity. The process of species emerging in urban areas is referred to as synurbization (Andrzejewski et al., 1978). Due to the synurbization, animals acquire new skills to live and utilize
Fig. 1. Adult foxes

Source: http://dinoanimals.pl/zwierzeta/ lis-vulpes-vulpes-rudy-spryciarz/attachment/lis-dinoanimals-pl-5/ new sources of food and to reproduce in the vicinity of humans (Champan \& Jones, 2012; Luniak 2008). The species observable in cities include, inter alia, rodents: the striped field mouse Apodemus agrarius (BabińskaWerka et al., 1979), the red squirrel (Sciurus vulgaris), (Verbelyen et al., 2003); birds, including the peregrine falcon (Falco pereginus; Rejt, 2001), and larger mammals, e.g. the badger (Meles meles), (Harris, 1984). The red fox (Vulpes vulpes) is also coping well in urban areas, thus enriching the urban fauna. However, the red fox is a zoonotic reservoir of parasites which can pose danger to human and animal health.

\section{Biology and prevalence}

The red fox is a predator belonging to the canids family. Mature specimens reach an approximate weight of 5-6 kg (Fig. 1). Females are smaller than males. The red fox breeds once a year, during winter months. On

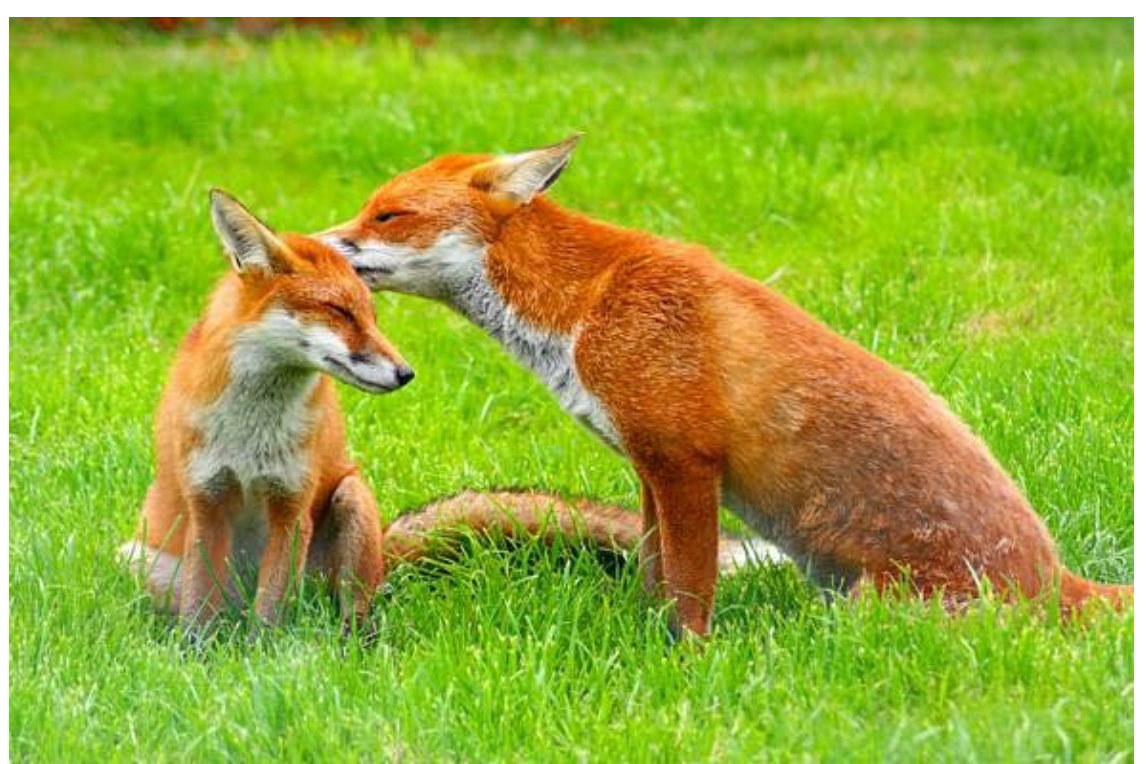


average, 3-5 pups are born which become self-sufficient after 3 months. The female cares for the young and the male helps feed the offspring by bringing the food near the burrow (http://animaldiversity.org/accounts/ Vulpes_vulpes/\#reproduction). It is the most common practice for foxes to dig burrows in a sandy ground (Scheldon, 1950) or to inhabit or even share the burrows dug by other animals, mainly the badger.

The fox is the world's most widespread predator (www.iucnredlist.org). It is present in Europe, North America, Asia, and it was also brought to Australia. It prefers field and forest habitats, mid-forest woodlots, and forest edges. The red fox is an omnivorous animal that mainly hunts for small-size rodents (Jędrzejewski \& Jędrzejewska, 1992; Dell'Arte et al., 2007). The research on fox's food base conducted in north-eastern Poland shows that voles are the main source of food for these predators. In addition, it has been stated that male and young foxes have a wider food base than females. The percentage of rodents in the diet increases in autumn and winter seasons (Kidawa \& Kowalczyk, 2011). The fox is an undesirable neighbor of poultry breeders. It can penetrate into farmlands, farms, and chicken coops where it has access to easy prey, ultimately leading to economic losses (Panek \& Breziński, 2002; Jankowiak et al., 2008; Baker et al., IFAW.org.).

\section{Fox population limiting factors}

The main factor that limits the fox population is rabies; however, the associated threat was effectively eliminated through vaccines spread on a massive scale across the forest areas. Since 1978, as many as $24 \mathrm{Eu}-$ ropean countries have been included in the program aimed to eradicate rabies. In 2007, the territory where fox vaccination campaigns were carried out, amounted to $21,077,370 \mathrm{~km}^{2}$ (Freuling et al., 2013). According

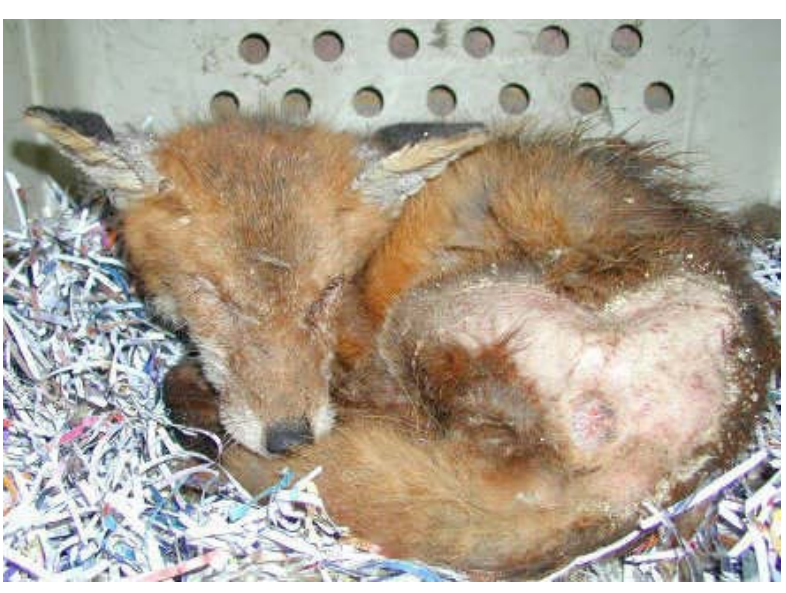

Fig. 2. Fox infected with scabies.

Source: http://www.nfws.org.uk/mange/mange_gallery.html

to the World Organization for Animal Health (OIE) countries where no single case of rabies have been detected, are considered virus-free. In Europe, such countries include, inter alia, the Netherlands (Clinguet et al., 2004), Austria (Muller et al., 2012), and Switzerland (Zannoni et al., 2000). In Poland, several dozen cases of rabies are reported on an annual basis (97 in 2015 with $70.1 \%$ relating to the red fox). Each case of rabies originated from the following 5 voivodships: WarmińskoMazurskie, Zachodnioporskie, Lubelskie, Małopolskie, and Podkarpackie (Flis, 2017). The specimen fallen due to rabies are found in the vicinity of human habitats (http://www.nowiny24.pl/wiadomosci/krosno/ art/6137625, uwaga-wscieklizna-w-krosnie,id,t.html).

Another factor that impacts the size of fox population is scabies. Scabies is classified in the group of infectious diseases caused by small-size mites (Sarcoptes scabiei). It is a widespread parasite that attacks 104 species of domestic and wild animals across Europe, North and South Americas, Australia, Asia, and Africa (Bornestein et al., 2001). It may be the cause lying behind human scabies (Madhusudhan Bandi \& Saikumar, 2013; Currie et al., 2004; Walton et al., 1999).

These small parasites are present in the host's skin tissue into which they burrow while feeding on the living tissue, tissue fluids, and epidermis (Arlian \& Vyszenski-Moher, 1988, https://www.cdc.gov/dpdx/ scabies/index.html).

The course of this disease depends on the condition and immune system of the animal. The most commonly observed symptoms include extensive allergic reactions, shedding, weight loss, and apathy (Little et al., 1995), (Fig. 2.). An extensive infection may lead to the death of the animal (Newman et al., 2002).

Scabies was the main cause of death in the population of foxes (particularly amongst the young specimens) monitored within the Bristol area between 1996-2007. In addition, it was demonstrated that females infected with this particular parasite had smaller litters and the puppies were in a much worse condition as compared to non-infected specimens (Sousbury et al., 2007). Death rate amongst the fox population prior to the emergence of scabies was approx. $10 \%$ per annum. After reporting the first infected fox in autumn of 1994, the death rate increased to $55 \%$ in the autumn season. Among the reported causes, scabies was the cause of $91 \%$ of fox deaths between the period of autumn 1994 and winter 1995. In addition, it was observed that the Bristol areas inhabited by fox family groupings had increased from $29.5 \pm 12.1$ ha in 1990 to $209.6 \pm 127.5$ ha in the winter season of 1995 (Baker et al., 2004). It was proved that, in the winter, foxes infected with scabies are less scared of people and are more frequently keen on selecting easily accessible sources of food (such as garbage) as compared to healthy specimens. The process of approaching human habitats and feeding the infected specimens may result in spreading scabies amongst humans and domestic animals (Cricondo-Sanchez, 2017). 
In addition, the size of the fox population is also significantly impacted by hunters' activities. The red fox is a game animal and the hunting season in Poland lasts from June 1 to March 31. In areas where the pheasant, capercaillie or hare are reintroduced, the fox hunting season can last all year. Nevertheless, the Polish population of foxes remains high. Between 1980 and 2006, there was a continuous increase in the number of foxes in central Poland (Goszczyński et al., 2008). Despite the hunting activities, high concentrations of the species were observed in surveys conducted between 1998/1999 and 2006/2007 in the eastern and central regions of the country. Interestingly, the largest number of foxes in the smallest survey area were recorded in the Bialskie district, while the smallest number in the largest survey area was reported in the Siedlce district (Bombik et al., 2014). In western Poland, over the 5 -fold higher density of this predator was recorded between 1997 and 2000 as compared to 1970 (Panek \& Breziński, 2002). According to the Polish Hunting Association, the fox population in Poland was estimated at 200,000 in the 2011/2012 hunting season (www.pzlow.pl, Fig. 3). In 2013, the population was estimated at 208,200. By the spring of 2015 , it had slightly decreased and was estimated at 191,000 specimens. To summarize, over a 4 -fold increase in the population of this predator has been observed as compared to the years preceding the application of the rabies vaccines (Panek \& Budny, 2015).

\section{The red fox in urban areas}

This particular predator accustoms itself perfectly to urban areas (Soulsbury et al., 2010; Lombardi et al., 2017) (Fig. 4). Fox concentrations in urban areas may reach quite high values (Harris \& Baker, 2001; Gosselink et al., 2003). In Estonia, the presence of foxes was reported in 33 of 47 large cities. The existence of fox burrows was reported even in downtown areas. Foxes are capable of entering households, thus posing a direct threat to humans and domestic animals. Several cases of dogs and cats attacked by foxes have been reported (Plumer et al., 2014). In Switzerland, fox burrows with offspring were reported in 20 large cities (Gloor et al., 2001).

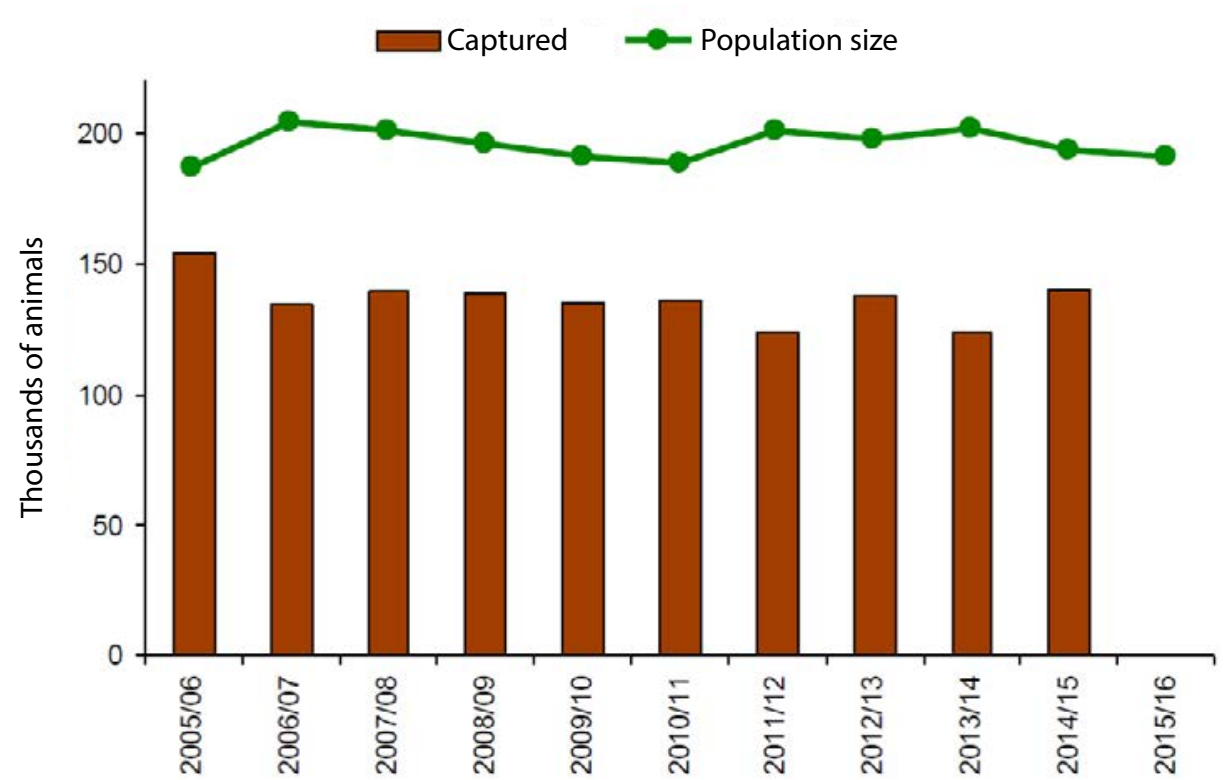

Fig. 3. Fox population in Poland

Source: www.pzlow.pl

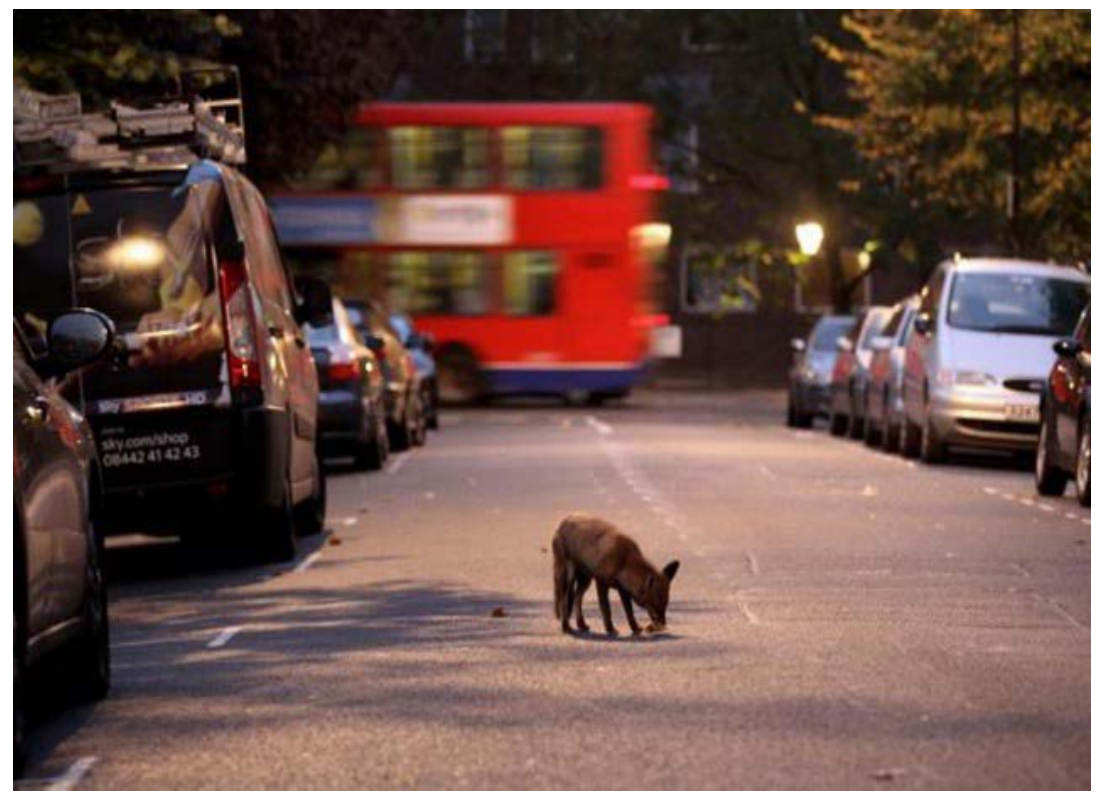

Fig. 4. The red fox in city streets

Source: http://www.athensvoice.gr/kosmos/alepoy-neo-katoikidio-toy-londinoy 
Specimens dwelling in urban areas are often spotted around dumpsters or in backyards (https://www.youtube.com/watch?v=IHeVJQPoy_w). As much as $80 \%$ of the content of the urban area fox digestive systems may comprise food of anthropological origin (Contesse et al., 2004). Animals inhabiting urban areas must cope with intensive road traffic which poses a direct life threat. Foxes can adapt their migrations to the type of crossed roads by selecting a small-traffic route and by crossing these routes at nighttime when traffic is at its lowest. Most frequently, the roads are crossed by males and the young while searching for a new territory (Baker et al., 2007). Adaptive skills, ability to use new sources of food and wide food base enable intensive expansion of the red fox to new areas, including downtowns (Bateman \& Fleming, 2012).

\section{Cyclophyllid tapeworm (Echinococcus multilocularis) and multilocular echinococcosis}

The red fox is a host for a number of dangerous parasites. By accessing urban areas, it increases the risk of exposure to the worms that pose danger from the medical and veterinary perspective. The cyclophyllid tapeworm (Echinoccocus multilocularis) poses the highest risk for humans. A mature tapeworm, measuring approximately 2-5 $\mathrm{mm}$ in length (Fig. 5), dwells in the fox's and less frequently in the dog's and cat's intestines. The infection may be very intensive and may exceed as many as 10000 tapeworms per specimen (Hoffer et al., 2000). Rodents are intermediate hosts of the tapeworm (https://www.cdc.gov/parasites/echinococcosis/biology.html). Currently, the E. multilocularis is assumed to be a global problem (Davidson et al., 2012). Tapeworms are common in numerous European countries, including Germany (Tackman et al., 1998), Slovakia (Dubinsky et al., 1999), Denmark (Saed at el., 2006), and
Sweden (Osterman et al., 2011). It also extends to Asia (Giraduoux et al., 2013) and North America (Jenkins et al., 2012). It is widely spread amongst the foxes inhabiting the urban areas of Japan (Tsukada et al., 2000). In Poland, the cyclophyllid tapeworm has also been reported (Karamon et al., 2014) with the largest range of infections registered in the foxes caught mainly in the Warmińsko-Mazurskie, Podkarpackie, and Mazowieckie Voivodships (Karamon et al., 2015), (Fig. 6.). The factors providing the favorable conditions for the spread of the parasite include, first and foremost, the quantity and synanthropization of the fox (remaining in the immediate vicinity of humans). In environments contaminated with fox excrements and tapeworm eggs, infected rodents may emerge that will fall prey to domestic cats and dogs. Ultimately, these specimens will become the end hosts of the tapeworm and excrete eggs that are invasive to humans (Deplazes et al., 1999; Knapp et al., 2016). It has been proved that, in urban conditions, this parasite may close its life cycle on the basis of synanthropic species of rodents, i.e. the intermediate hosts. E. multilocularis cysts (larvae) have been reported in the European water vole (Arvicola terrstis) caught in Zurich (Hofer et al., 2000). Numerous studies confirming the presence of the E. multilocularis in foxes inhabiting the urban areas of many European countries, (Fisher et al., 2005; Robarded et al., 2008), show the widespread presence of this particular parasite posing potential risks for humans. Humans are threatened by contact with fox excrements and excrement-contaminated soil, e.g. in suburban gardens, parks, or forests.

The parasite causes an illness referred to as multilocular echinococcosis. The first case of the disease was described by Buhl in 1852 (Hosemann et al., 1928). Humans contract this disease by swallowing tapeworm eggs, thus becoming accidental hosts (Fig. 7). While in a human body, the larva hatches from the egg and, as it is not surrounded by any connective tissue, it quite easily spreads with blood and lymph to other organs (Czapliński \& Kurnatowski, 1999). The studies conducted in Germany on a group of 120 patients with confirmed echinococcosis show that persons at risk of exposure to E. multilocularis include inhabitants of rural areas, dog and cat owners, persons who either consume

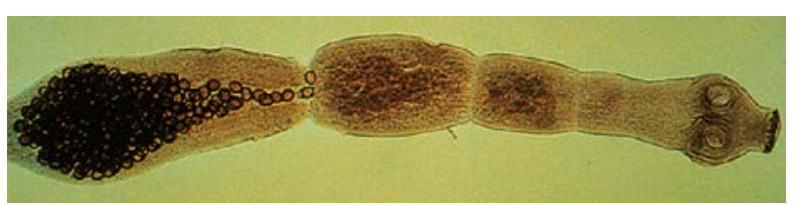

Fig. 5. Echinococcus multilocularis - adult form Source: http://research.vet.upenn.edu/Default.aspx?Tabld=7812

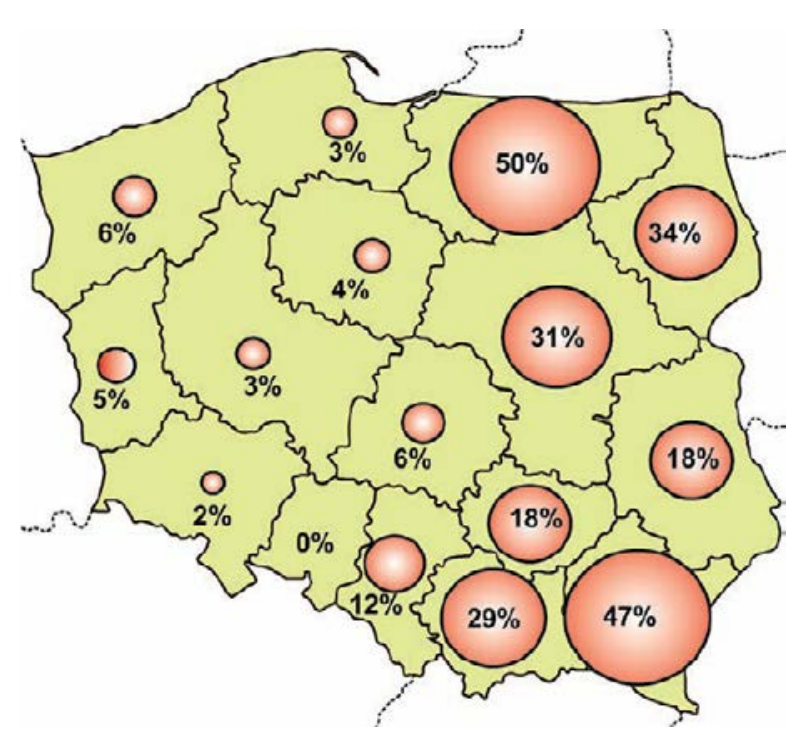

Fig. 6. Foxes infected with E. multilocularis between 20092013 in Poland

Source: Karamon J, Kochanowski M, Dąbrowska J, Różycki M, Bilska-Zając E, Sroka J, Cencek T (2015). Echinococcus multilocularis w Polsce - sytuacja epizootyczna u lisów wskaźnikiem ryzyka zarażenia ludzi. Życie Weterynaryjne 90(9) 
unwashed fruits, vegetables, and grass or collect wood in forests, and persons with occupations related to forest areas (Kern et al., 2004). Traces of tapeworm DNA were discovered on fruits, vegetables and mushrooms originating from the Warmińsko-Mazurskie Voivodship, i.e. the area of Poland assumed to be endemic for the cyclophyllid tapeworm. The parasite's genetic material has been discovered with the use of molecular biology methods featuring sensitivity rates of above 100 eggs per tested sample. This proves the high significance of the food contaminated with eggs as a direct source of risk to humans. This is why it is important to educate communities living in areas endemic for E. multilocularis on means of prevention and threats resulting from failure to adhere to hygiene rules while preparing meals of fruits and vegetables that may contain tapeworm eggs (Lass et al., 2015). It is worth noting that the eggs of this particular tapeworm show extreme resistance to environmental factors. At $4{ }^{\circ} \mathrm{C}$, they preserve the ability to remain immune to any type of intrusion for 478 days and for 240 days at $-18^{\circ} \mathrm{C}$. It is not until the temperature reaches $-83^{\circ} \mathrm{C} /-196^{\circ} \mathrm{C}$ that the eggs are killed within 48 / 20 hours respectively. The eggs are also immune to numerous chemical agents (Veit et al., 2009). The echinococcosis development process is similar to the development of cancer, with which the echinococcosis is often confused, and may last from 10 to 15 years. In case of non-treatment or improper treatment due to misdiagnosis, it may lead to death. Unfortunately, despite the quick diagnosis and properly selected therapy, the patient will ultimately lose his battle with the disease (Davis et al., 1986). It often happens that the symptoms are non-specific and depend on the location of the cyst in the body. Cysts are typically located in the liver, less commonly in the brain, heart or lungs. The non-specific symptoms include, inter alia, weight loss, upper and lower abdominal pain, hepatitis, apathy, ascites, swollen

\section{Echinococcus multilocularis}

END HOSTS

they eat infected rodents

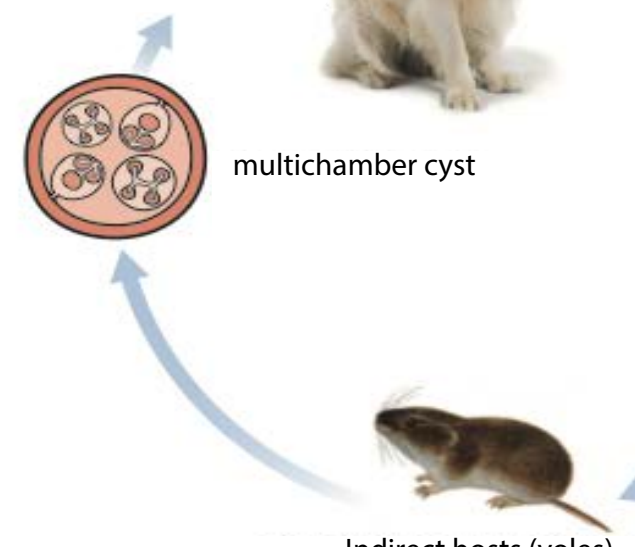

Indirect hosts (voles) they swallow eggs from the environment

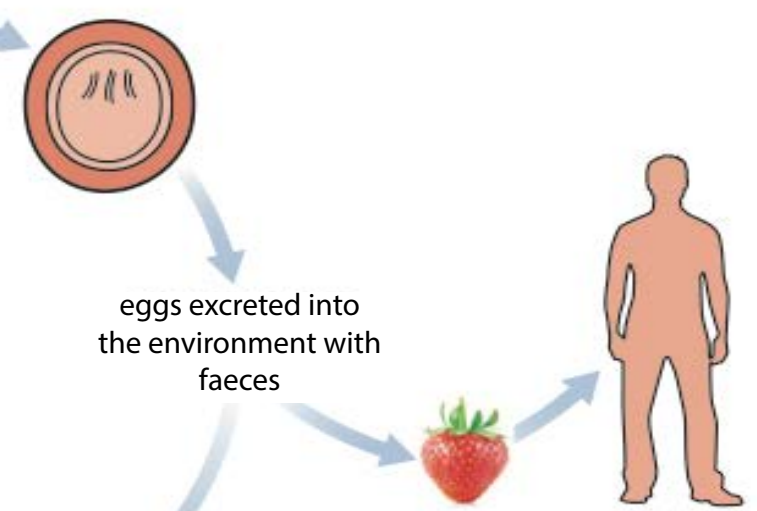

people swallow eggs from infected end hosts or with contaminated food

Fig. 7. The life cycle of E. multilocularis

Source: http://esccap.pl/wpcontent/uploads/2017/08/Cykl_rozwojowy_bablowiec_wielojamowy_Echinococcus_multilocularis.png

shanks, tachycardia (Pawłowski et al., 2001; Parfieniuk et al., 2009). The most effective method of removing the tapeworm is the surgical removal of cysts and long-term drug treatment based primarily on anti-parasitic medicine such as Albendazole and Mebendazole (Brunetti et al., 2010). The cases of multilocular echinococcosis are reported mainly in France (Pirraux et al., 2011), Germany (Romig et al., 1999), Lithuania (Sarkunas et al., 2010), and Switzerland (Schweiger et al., 2007). The first descriptions of multilocular echinococcosis patients in Poland come from 1951 and 1958 (Sowiakowski, 1955; Głuszcz \& Kalczak, 1960). Between the years of 1990-2011, an increased number of multilocular echinococcosis cases was reported. The majority (57.3\%) of the cases were reported in the Warmińsko-Mazurskie Voivodship believed to be an endemic region for E. $m u l-$ tilocularis. Research conducted for over 20 years has included 121 cases of echinococcosis registered by the 
Chief Sanitary Inspectorate. It included the ELISA and Western Blot tests that enabled the discovery of specific antibodies to the parasite in the patient's serum. In several cases, molecular biology methods (polymerase chain reaction; PCR) were also applied to discover the parasite's genetic material (Nahorski et al., 2013).

\section{Summary}

The red fox is a predator well-accustomed to dwell in all types of environments from forests to big city downtowns. Despite several significant factors that limit its quantities, an increase in this predator's population has been observed across a number of countries. This particular species enrich the urban fauna by becoming its permanent element. However, the presence of the fox in the vicinity of humans brings along a threat from the parasites for which the predator serves as the host. The most dangerous is the cyclophyllid tapeworm (E. multilocularis) causing multilocular echinococcosis a deadly disease for humans. Monitoring the fox population and continuing the research on E. multilocularis may help take actions to prevent the infection process.

\section{References}

Andrzejewski R, Babińska-Werka J, Gliwicz J, Goszczyński J (1978). Synurbization processes in an urban population of Apodemus agrarius. Characteristic of population in urbanization gradient. Acta Theriol 23:341-358

Arlian LG, Vyszenski-Moher DL (1988). Life Cycle of Sarcoptes scabiei var. Canis. J Parasitol 74: 427-430

Babińska-Werka J, Gliwicz J, Goszczyński J (1979). Synurbization processes in a population of Apodemus agrarius. II. Habitats of the striped field mouse in town.Acta Theriol 24:405-415

Baker P, Funk S, Harris S, Newman T, Saunders G, White P (2004). The impact of human attitudes on the social and spatial organization of urban foxes (Vulpes vulpes) before and after an outbreak of sarcoptic mange. Proceedings 4th International Urban Wildlife Symposium Shaw et al., Eds. 2004, 153-163
Baker P, Harris S, White P After the hunt: The future for foxes in Britain. IFAW org. University of Bristol, University of York:http:// www.ifaw.org/united-kingdom/resource-centre/after-hunt-future-foxes-britain

Baker PJ, Dowding CV, Molony SE, White PCL, Harris S (2007). Activity patterns of urban red foxes (Vulpes vulpes) reduce the risk of traffic-induced mortality. Behav Ecol 18:716-724

Bandi KM, Saikumar C (2013). Sarcoptic Mange: A Zoonotic Ectoparasitic Skin Disease. J Clin Diagn Res 7:156-157

Bateman PW and Fleming PA (2012). Big city life: carnivores in urban environments. J Zool 287:1-23

Contesse P (2004). The diet of urban foxes (Vulpes vulpes) and the availability of anthropogenic food in the city of Zurich, Switzerland. Zeitschrift für Säugetierkunde 69:81-95

Currie BJ, Harumal P, McKinnon M, SF (2004). First Documentation of In Vivo and In Vitro Ivermectin Resistance in Sarcoptes scabiei. Clin Infect Dis 39:e8-e12

Czapliński B, Kurnatowski P (1999) in: Kadłubowski R. Zarys parazytologii lekarskiej. Wydawnictwo Lekarski PZWL, ed. 7, Warszawa, pp 236-237

Davidson RK, Romig T, Jenkins E, Tryland M, Robertson LJ (2012). The impact of globalisation on the distribution of Echinococcus multilocularis. Trends Parasitol 28:239-247

Dell'Arte GL, Laaksonen T, Norrdahl K, Korpimäki K (2007). Variation in the diet composition of a generalist predator, the red fox, in relation to season and density of main prey. Acta Oecol 31:276-281

Deplazes P, Alther P, Tanner I, Thompson RC, Eckert J (1999). Echi nococcus multilocularis detection by enzyme-linked immunosorbent assay in fox, dog and cat populations. J Parasitol 85:115-121

Gloor S, Bontadina F, Hegglin D, Deplazes P, Breitenmoser U (2001). The rise of urban fox populations in Switzerland. Mamm Biol 66:155-164

Głuszcz A, Kalczak M (1960) Echinococcus alveolaris-a rare form of the echinococcus of the liver Pol Tyg Lek 15:559-562)

Gosselink TE, Van Deelan TR,Warner RE, Joselyn MG (2003). Temporal habitat partitioning and spatial use by coyotes and red foxes in east central Illinois. J Wildl Manag 67:90-103

Goszczyński J, Misiorowska M, Juszko S (2008). Changes in the density and spatial distribution of red fox dens and cub numbers in central Poland following rabies vaccination. Acta Theriol 53:121127

Harris S (1984). Ecology of Urban badgers Meles meles: Distribution in Britain and habitat selection, persecution, food and damage in the city of Bristol. Biol Cons 28:349-375

Harris S, Baker P (2001). Urban foxes. Whittet Books, Stowmarket, Suffolk Harrison RL

Hofer S, Gloor S, MuËller U, Mathis A, Hegglin D, Deplazes P (2000). High prevalence of Echinococcus multilocularis in urban red foxes
(Vulpes vulpes) and voles (Arvicola terrestris) in the city of Zurich, Switzerland. Parasitology 120:135-142

Hosemann G, Schwarz E, Lehmann C, Posselt A. Die Echinokokkenkrankheit. Stuttgart: F. Enke, 1928. pp. 1-418

http://animaldiversity.org/accounts/Vulpes_vulpes/\#reproduction

http://www.nowiny24.pl/wiadomosci/krosno/art/6137625, uwagawscieklizna-w-krosnie,id,t.html

https://www.cdc.gov/dpdx/scabies/index.html

https://www.cdc.gov/parasites/echinococcosis/biology.html

https://www.youtube.com/watch?v=IHeVJQPoy_w

Hunter P (2007). The human impact on biological diversity. How species adapt to urban challenges sheds light on evolution and provides clues about conservation. Eur Mol Biol Org 8, 4

Jankowiak Ł, Antczak M, Tryjanowski P (2008). Habitat use, food and the importance of poultry in the diet of the red fox Vulpes vulpes in extensive farmland in Poland. World Appl Sc J 4:886890

Jenkins EJ, Peregrine AS, Hill JE, Somers C, Gesy K, Barnes B, Gottstein B, Polley L (2012). Detection of European Strain of Echinococcus multilocularis in North America. Emerg Infect Dis 18:1010-1012

Jędrzejewski W, Jędrzejewska B (1992). Foraging and diet of the red fox Vulpes vulpes in relation to variable food resources in Biatowieża National Park, Poland. Ecography 15:212-220

Karamon J, Kochanowski M, Sroka J, Cencek T, Różycki M, Chmurzyńska E, Bilska-Zając E, (2014). The prevalence of Echinococ cus multilocularis in red foxes in Poland-current results (20092013). Parasitol Res, 113:317-322

Karamon J, Kochanowski M, Dabrowska J, Różycki M, Bilska-Zając E, Sroka J, Cencek T (2015). Echinococcus multilocularis w Polsce- sytuacja epizootyczna u lisów wskaźnikiem ryzyka zarażenia ludzi. Życie Weterynaryjne 90(9)

Kern P, Ammon A, Kron M, Sinn G, Sander S, Petersen LR, Gaus W, Kern P (2004). Risk Factors for Alveolar Echinococcosis in Humans Sander. Emerg Infect Dis 10:2088-2093

Kidawa D and Kowalczyk R (2011). The effects of sex, age, season and habitat on diet of the red fox Vulpes vulpes in northeastern Poland. Acta Theriol 56: 209-218

Knapp J, Combes B, Umhang G, Aknouche S, Millon L (2016). Could the domestic cat play a significant role in the transmission of $E c h i$ nococcus multilocularis? A study based on $\mathrm{qPCR}$ analysis of cat feces in a rural area in France. Parasite: 23:1-7

Lass A, Szostakowska B, Myjak P, Korzeniewski K (2015). The first detection of Echinococcus multilocularis DNA in environmental fruit, vegetable, and mushroom samples using nested PCR. Parasitology Res 114:4023-4029

Little SE, Davidson WR, Rakich PM, Nixon TL, Bounous DI, Nettles VF (1998). Responses of red foxes to first and second infection 
with Sarcoptes scabiei. J Wildl Dis $34: 600-611$

Lombardi JV, Comer CE, Scognamillo DG, Conway WC (2017). Coyote, fox, and bobcat response to anthropogenic and natural landscape features in a small urban area. Urban Ecosyst DOI 10.1007/ s11252-017-0676-z

Luniak M (2008). Fauna of the big city - estimating species richness and abundance in Warsaw, Poland. Urban Ecol 4:349-354

Muller T Bätza HJ, Freuling C, Kliemt A, Kliemt J, Heuser R, Schlüter H, Selhorst T, Vos A, Mettenleiter TC (2012). Elimination of terrestrial rabiesin Germany using oral vaccination of foxes. Berl. Muench Tieraerztl Wochenschr 125:178-190

Nahorski WL, Knap JP, Pawłowski ZS, Krawczyk M, Polański J, Stefaniak J, Patkowski W, Szostakowska B, Pietkiewicz H, Grzeszczuk A, Felczak-Korzybska I, Gołąb E, Wnukowska N, Paul M, Kacprzak E, Sokolewicz-Bobrowska E, Niscigorska-Olsen J, Czyrznikowska A, Chomicz L, Cielecka D, Myjak P (2013). Human Alveolar Echinococcosis in Poland: 1990-2011. PLos Negl Trop Dis 7:1-8.

Newman TJ, Baker PJ, Harris S (2002). Nutritional condition and survival of red foxes with sarcoptic mange. Can J Zool 80:154-61

Osterman Lind E, Juremalm M, Christensson D, Widgren S, Hallgren G, Ågren EO Uhlhorn H, Lindberg A, Cedersmyg M, Wahlström H (2011). First detection of Echinococcus multilocularis in Sweden, February to March 2011. Euro Surveill 7: 16(14)

Panek M, Bresiński W (2002). Red fox Vulpes vulpes density and habitat use in a rural area of western Poland in the end of 1990s, compared with the turn of 1970s. Acta Theriol 47:433-442

Panek M, Budny M (2015). Sytuacja zwierzyny łownej w Polsce ze szczególnym uwzględnieniem kuropatwy, na podstawie badań monitoringu. Stacja Badawcza PZŁ Czempiń 12-13

Parfieniuk A, Łapiński T, Kalinowska A, Flisiak R (2009). Trudności diagnostyczne towarzyszące rozpoznaniu bąblowicy wielokomorowej wątroby. Przewodnik Lekarza 4:105-106

Plumer L, Davison J, Saarma U (2014). Rapid urbanization of red Foxes in estonia: Distribution, Behaviour, Attacks on Domestic Animals, and Health-Risks Related to Zoonotic Diseases. PLoS ONE 1-15

Rejt $€$ (2001). Feeding Activity and Seasonal Changes in Prey Composition of urban Peregrine Falcons Falco peregrinus.Acta Ornithol 36:165-169

Romig T, Kratzer W, Kimmig P, Frosch M, Gaus W, Flegel WA, Gottstein B, Lucius R, Beckh K, Kern P (1999). An epidemiologic survey of human alveolar echinococcosis in southwestern Germany. Römerstein Study Group. Am J Trop Med Hyg 61:566-573

Sanchez DR, Odden M, Linnell JDC, Odden J (2017). The range of the mange: Spatiotemporal patterns of sarcoptic mange in red foxes (Vulpes vulpes) as revealed by camera trapping. PLoS ONE 19:1-16

Šarkūnas M, Bružinskaitè R, Marcinkutè A, Strupas K, Sokolovas
V, Marcinkute A, Strupas K, Sokolovas V, Mathis A Deplazes P (2010). Emerging alveolar echinococcosis (AE) in humans and high prevalence of Echinococcus multilocularis in foxes and raccoon dogs in Lithuania. Acta Vet Scand 52:1-3

Schweiger A, Ammann RW, Candinas D, Clavien PA, Eckert J, Gottstein B, Halkic N, Muellhaupt B, Prinz BM, Reichen J, Tarr PE, Torgerson PR, Deplazes P (2007). Human Alveolar Echinococcosis after Fox Population Increase, Switzerland. Emerg Infect Dis. 13:878-882

Sowiakowski J (1955). Echinococcus alveolaris Pol Tyg Lek 10:46-52 Tsukada H, Morishima Y, Nonaka N, Oku Y, Kamiya M (2000). Preliminary study of the role of red foxes in Echinococcus multilocularis transmission in the urban area of Sapporo, Japan. Prasitology 120:423-428

Veit P, Bilger B, Schad V, Schäfer J, Frank W, Lucius R (1995). Influence of environmental factors on the infectivity of Echinococcus multilocularis eggs. Parasitology 110:79-86

Vitousek PM, Mooney HA, Lubchenco J, Melillo JM (1997). Human domination of Earth's ecosystems. Science 277:494-499

Walton SF, McBroom J, Mathews DJ, Kemp DJ, Currie BJ (1999). Crusted Scabies: A Molecular Analysis of Sarcoptes scabiei Variety hominis Populations from Patients with Repeated Infestations. Clin Infect Dis 29:1226-1230

http://www.pzl.pl 